DOI https://doi.org/10.51647/kelm.2020.4.3.12

MONITORING KRYMINOLOGICZNY I JEGO CECHY

\author{
Yurii Tarasevych \\ aspirant Katedry Prawa Administracyjnego i Karnego Dniepropetrowskiego Narodowego Uniwersytetu \\ imienia Otesia Honczara \\ ORCID ID: 0000-0003-4414-958X \\ Tarasevych89@gmail.com
}

\begin{abstract}
Adnotacja. Wykazano, że monitorowanie kryminologiczne jest uważane za jeden z najskuteczniejszych środków kontroli w dziedzinie zarządzania przeciwdziałaniem przestępczości w nauce. Postępowanie w sprawie kryminologicznego monitorowania regulacji prawnych otwiera szerokie możliwości zapewnienia moderatorów systemu przeciwdziałania przestępczości w odniesieniu do stanu faktycznego, a także dynamiki zmian i przewidywanych parametrów w obiekcie wpływów karnych i prewencyjnych, biorąc pod uwagę przepisy dotyczące normatywnych determinacji przestępczości. Monitorowanie kryminologiczne skuteczności regulacji prawnej ma na celu zapewnienie terminowego i pełnego informowania szczebla kierowniczego podmiotów przeciwdziałania przestępczości względem rzeczywistego i potencjalnego stanu odtwarzania niekorzystnych czynników oddziaływania elementów pozytywnego prawa na sytuację kryminologiczną, kształtowanie informacyjnego modelu prawnego determinacji przestępczości w ogóle w celu organizacji stałego wpływu korygującego w zakresie dalszych procedur badawczych (badania kryminologiczne) i praktycznych (działalność ustawodawcza).

Słowa kluczowe: monitoring kryminologiczny, skuteczność regulacji prawnych, skuteczność kryminologiczna aktów prawnych, kryteria, przeciwdziałanie przestępczości.
\end{abstract}

\title{
CRIMINOLOGICAL MONITORING AND ITS FEATURES
}

\author{
Yuri Tarasevich \\ Postgraduate student of the Department of Administrative and Criminal Law \\ Oles Honchar Dnipro National University \\ ORCID ID: 0000-0003-4414-958X \\ Tarasevych89@gmail.com
}

\begin{abstract}
It is shown that one of the most effective means of control in the field of crime management in science is considered to be criminological monitoring. Criminological monitoring of legal regulation opens wide opportunities for information support of moderators of the crime prevention system on the actual situation, as well as the dynamics of changes and projected parameters in the object of criminal prevention, taking into account the provisions on regulatory determination of crime. Being substantively and procedurally quite complex formation in the system of crime prevention, criminological monitoring reflects, on the one hand, segmentation in accordance with the structural elements of the subject of criminological science, being in some cases a linking chain that combines knowledge of criminogenic determination, prevention, crime prevention features of a technique and the organization of criminological researches, criminological forecasting and planning. Criminological monitoring of the effectiveness of legal regulation is aimed at ensuring timely and comprehensive information of the management of the fight against crime about the actual and potential state of reproduction of adverse factors of positive law elements on the criminogenic situation, to form an information model of legal determination of crime in general organization of constant corrective influence within the limits of further research (criminological examination) and practical (law-making activity) procedures. Further development of the methodology of criminological monitoring should be associated, firstly, with the use of the whole causal complex of crime, in the presence of which this scenario can be implemented, and secondly, with the simplification of digitalization of crime and socio-economic, criminological indicators its signs. In addition, the methodology should be based on systems that can autonomously process information, generate indicators in the form of adaptive responses, without taking into account the subjective opinion of researchers.

Key words: criminological monitoring, efficiency of legal regulation, criminological efficiency of normative legal acts, criteria, counteraction to crime.
\end{abstract}

\section{КРИМІНОЛОГІЧНИЙ МОНІТОРИНГ ТА ЙОГО ОСОБЛИВОСТІ}

\section{Юрій Тарасевич}

аспірант кафедри адміністративного та кримінального права Дніпропетровського Національного університета імені Олеся Гончара

ORCID ID: 0000-0003-4414-958X

Tarasevych89@gmail.com

Анотація. Показано, що одним з найбільш ефективних засобів контролю у сфері управління протидією злочинності в науці прийнято вважати кримінологічний моніторинг. Провадження кримінологічного моніторингу 
правового регулювання відкриває широкі можливості інформаційного забезпечення модераторів системи протидії злочинності щодо дійсного стану, а також динаміки змін та прогнозованих параметрів в об'єкті кримінально-превентивного впливу з урахуванням положень про нормативно-правову детермінацію злочинності. Кримінологічний моніторинг ефективності правового регулювання спрямований на спрямований на забезпечення своєчасного й всебічного інформування управлінської ланки суб'єктів протидії злочинності щодо дійсного й потенційно можливого стану відтворення несприятливих факторів впливу елементів позитивного права на криміногенну ситуацію, формувати інформаційну модель нормативно-правової детермінації злочинності в цілому з метою організації постійного корегуючого впливу в межах подальших дослідницьких (кримінологічна експертиза) й практичних (правотворча діяльність) процедур.

Ключові слова: кримінологічний моніторинг, ефективність правового регулювання, кримінологічна ефективність нормативно-правових актів, критерії, протидія злочинності.

Вступ. Історія розвитку моніторингу в нашій країні органічно переплетена із зародженням, становленням і розвитком наукової прогностики. У сфері протидії злочинності системні її вивчення почалися в кінці 60-х - на початку 70-х pp. XX ст. 3 аналізу Є. М. Блажівським питань причин злочинності і корелюючих факторів. У той час державними інститутами вивчалася злочинність на різних рівнях, аналізувалися її кількісні та якісні характеристики, розглядалися особливості правопорушників, визначався комплекс факторів, що детермінують злочинність (Блажівський, 2013: 159).

Таким чином, кримінологічний моніторинг - це системна відповідь на складні виклики й загрози національній безпеці з боку злочинності. Він з'являється як закономірний результат реалізації міждисциплінарного підходу в кримінологічних дослідженнях і запозичення для вирішення власних специфічних завдань найбільш придатних методичних та організаційних інструментів із суміжних галузей знань. Аналіз наукової літератури з даної проблематики дозволяє нам припустити, що кримінологічний моніторинг $є$ одним з найбільш ефективних засобів протидії злочинності в сучасному науковому уявленні. Відомо, що в системі протидії злочинності існують певні закономірності, які виражають логіку розвитку тих чи інших процесів i саме якісний кримінологічний моніторинг може дати більш повну картину наведених закономірностей, видозмінити їх за необхідності. Здійснення кримінологічного моніторингу поліції - відносно нова сфера досліджень, яка, проте, динамічно розвивається з кожним днем (Коваленко, 2018: 92).

Мета дослідження полягає в аналізі сутності головного поняття теми дослідження, розкритті об’єкту, завдань, недоліків та областей застосування кримінологічного моніторингу.

Основна частина. Аналіз останніх досліджень, публікацій та нормативно-правової бази України засвідчив, що в юридичній науці питання кримінологічного забезпечення поліцейської діяльності загалом не знайшло свого цільового комплексного висвітлення. Важливими є дослідження таких науковців, як Н. В. Сметаніна (Сметаніна, 2016: 192), А. В. Коваленко (Коваленко, 2018: 131), Ю. В. Орлов (Орлов, 2016: 656), А. П. Закалюк (Закалюк, 2008: 320), Г. А. Аванесова, Б. М. Головкіна, В. К. Грищука, Л. М. Давиденка, О. М. Джужи, В. П. Ємельянова, А. П. Закалюка, Т. В. Корнякової, О. М. Костенка.

Існує значна кількість способів і методів розслідування злочинів. Водночас існує низка додаткових процедур, без яких ефективність розслідування злочину або здійснення поліцією превентивної функції, може бути поставлені під сумнів. Одним із таких механізмів є кримінологічний моніторинг, функціонування якого в сучасних умовах діяльності поліції є необхідним, але з точки зору теорії недослідженим і практично не апробованим.

Д. М. Миронюк, виходячи з методологічної настанови концепції кримінологічної безпеки, зазначає, що кримінологічний моніторинг - це процес систематичного спостереження, аналізу й оцінки стану та тенденцій злочинності, іiї чинників та особливостей особистості злочинця, які впливають на його злочинну поведінку, діяльності щодо запобігання злочинам, рівня захищеності об'єктів можливого злочинного посягання, ступеня готовності всього населення протидіяти злочинності (Орлов, 2014: 163). Дещо ширше трактування поняття дають А. В. Коваленко (Коваленко, 2019: 164) й О. М. Литвинов, пропонуючи розуміти його як визначену практичною необхідністю наукову, засновану на пізнанні закономірностей розвитку певного явища і процесу, постійно функціонуючу систему спостереження, вимірювання й оцінки їхніх станів у різні періоди. Отже, зміст кримінологічного моніторингу становлять процеси отримання, оброблення й аналізу необхідної для формулювання кінцевих висновків інформації.

Кримінологічний моніторинг не варто ототожнювати 3 повномасштабним кримінологічним дослідженням. У цьому контексті слушною є думка Ю. В. Орлов, який зазначає, що кримінологічний моніторинг не вирізняється особливою глибиною досліджень, його завдання - забезпечення своєчасного реагування на системні зміни (Орлов, 2016: 263). Автор вважає, що з розумінням моніторингової діяльності як дослідження суто прикладного, обслуговуючого, а не фундаментального значення, варто погодитися. Є. М. Блажівський виділяє вузьке та широке поняття кримінологічного моніторингу (Блажівський, 2013: 127). У вузькому значенні під кримінологічним моніторингом розуміти відкриту, динамічну, нелінійну постійно діючу систему спостереження, змістом якої є здійснювані на науковій основі збирання, аналіз, узагальнення та оцінка кримінологічно значущих явищ, процесів і станів об’єктів у різні періоди часу з метою підвищення (підтримання) ефективності управління протидією злочинності. У широкому ж- спеціалізовану постійно функціонуючу інформаційну технологію забезпечення ефективного кримінологічного аналізу, прогнозування та контролю в системі протидії злочинності, засіб під тримання іiі адаптивності й інтеграції із соціальним середовищем. Також, на думку зазначеного науковця, моніторинг детермінантів злочинності передбачає спостереження як за наявними, так і за потенційними криміногенними чинниками. 
Під час розроблення професіограм прокурорів різного рівня В. Л. Васильєв звернув увагу на те, що мислення зазначених осіб спрямоване на виявлення причин конкретного явища, тому має причинно-наслідковий характер. Такі якості мислення зумовлюють наявність у прокурора здібностей різнопланового характеру (Національний університет внутрішніх справ Харків, 2021: 210).

Є. М. Блажівський виділяє: - економіко-кримінологічний моніторинг (Блажівський, 2013: 162). Проблеми цього виду моніторингу у вітчизняній науці розглядалися здебільшого в працях В. М. Поповича; - політикокримінологічний моніторинг є перспективним видом моніторингу, який останнім часом належно висвітлено у вітчизняній кримінології завдяки розробленню проблематики політичної злочинності та засобів протидії їй; - психолого-кримінологічний моніторинг - різновид моніторингового дослідження, який застосовується здебільшого на індивідуальному та груповому рівнях кримінологічної профілактики; - моніторинг ступеня криміналізації суспільства загалом, а також окремих соціальних груп, який охоплює, по-перше, моніторинг змін у рівні та структурі судимості, що здійснюється на підставі статистичних даних щодо кількості осіб, притягнутих до кримінальної відповідальності, співвідношення окремих їх категорії за різними критеріями (соціально-демографічні, кримінально-правові, кримінологічні).

Проведені С. М. Блажівським експерименти із застосуванням нейронних мереж продемонстрували широкі можливості у виявленні регіональних особливостей злочинності в Україні та одержанні сценаріїв розвитку тенденцій злочинності й кримінальної ситуації в середньостроковій перспективі (Блажівський, 2013: 290).

Головними об'єктами моніторингу протидії злочинності є: злочинність у єдності їі стану, структури та динаміки; фонові для злочинності явища; соціальні наслідки злочинності, їі ціна; детермінанти злочинності (як дійсні, так і прогнозовані); ступінь криміналізації суспільства в цілому, а також окремих соціальних груп; індивідуальні злочинні прояви в динаміці змін в окремих складових їх механізму залежно від об’ єкту посягання, способів, засобів і мотивів вчинення злочину; стан протидії злочинності; стан і тенденції розвитку науки кримінології.

Найближчими цілями кримінологічного моніторингу, завдяки досягненню яких реалізуються всі попередні, є збирання, аналіз, узагальнення й оцінювання кримінологічної інформації за критеріями належності, що визначаються метою вищого порядку. Вважаємо, що одержання кримінологічної інформації є не самоціллю моніторингу протидії злочинності, а його завданням (тобто не стратегічною, а тактичною метою найнижчого рівня за схемою древа цілей), виконання якого покликане забезпечити таку кінцеву мету, як підвищення (підтримання) ефективності управління протидією злочинності.

Головними умовами застосування кримінологічного моніторингу є таке: між показниками, що характеризують фактори злочинності, причини й умови злочинів, з особою злочинця має бути зв’язок; використання даної методики можливо, коли встановлено зв’язок між показниками; для здійснення сценарію має бути підготовлено набір показників, що характеризують фактори, причини, умови, особистість досліджуваних, що являє собою ряд спостережень за безліччю об'єктів, вивчення яких передбачається; для поліпшення достовірності сценарію необхідна велика кількість спостережень; не можна допускати обмеження й категоричності даних досліджень.

Таким чином, застосування кримінологічного моніторингу як спеціалізованої інформаційної технології має на меті забезпечення ефективного кримінологічного аналізу, прогнозування та контролю в системі протидії злочинності. І якщо про сприяння прогнозуванню йшлося вище, то в разі аналізу широкого підходу до визначення кримінологічного моніторингу останній виводиться на рівень його розуміння саме як інструменту реалізації контролю в управлінні протидією злочинності.

Якщо розглядати етимологічне походження поняття «моніторинг», слід зауважити, що моніторингом зазвичай вважають спеціально організоване систематичне спостереження за станом об'єктів, явищ, процесів 3 метою їхньої оцінки, контролю та прогнозу. Популярним є використання терміна «моніторинг», коли йдеться про спостереження за станом навколишнього середовища (атмосфери, гідросфери, грунту, рослинного покриву, а також техногенних систем) з метою їх охорони та здійснення певного прогнозу. Проте коли розглядають моніторинг конкретних, а ще важливіше - складних соціальних явищ, то немає чітких критеріїв, які б могли допомогти відслідкувати динаміку змін. Подібне можливо лише при комплексному системному підході, який грунтується на наукових методиках та програмах (Закалюк, 2008: 117).

Сучасна наука тлумачить поняття «моніторинг» як постійне спостереження за яким-небудь процесом 3 метою виявлення його відповідності бажаному результату або первісним пропозиціям (у зв’язку з господарською діяльністю спостереження, оцінювання й прогнозу стану навколишнього середовища). Цікавою є думка Д. М. Миронюка (Миронюк, 2014: 161), який у своїх дослідженнях стверджує, що кримінологічний моніторинг є елементом профілактики злочинності, що наскрізь проходить через всю кримінальну політику держави та має аналітичний характер. Моніторинг - це спостереження за чітко визначеним об'єктом. Зазначений термін походить від латинського слова «monitor», тобто «застережливий» (якщо продовжувати синонімічний ряд, з'ясуємо, що моніторинг - це не лише спостереження, а й нагляд, нагадування тощо).

Не можна оминути увагою той факт, що в контексті кримінологічного моніторингу важливим є не лише стан злочинності, який наявний на певній території сьогодні, а й те, яким він був у минулому та яким планується його бачення в майбутньому. 3 огляду на це, кримінологічний моніторинг - не разове явище, що має відбуватися $з$ певною постійністю. Різні вчені по-своєму представляють схему кримінологічного моніторингу, але певні аспекти в їх дослідженнях часто збігаються, що дає змогу дійти думки у єдності підходів 
більшості вчених до наукового тлумачення кримінологічного моніторингу (Збірник тез між народ.наук.практ. круглого столу, Київ, 2019: 66).

Так, наприклад, Є. М. Блажівський представляє схему кримінологічного моніторингу через три галузі діяльності: як управлінську діяльність, оперативно-розшукову (на нашу думку, сюди входить також науковопошукова діяльність) і практичну (Блажівський, 2013: 165). Поєднані між собою зазначені галузі діяльності утворюють таке бачення кримінологічного моніторингу: чітке визначення щодо того, яку мету переслідує кримінологічний моніторинг та які завдання ставляться перед ним; визначення з тим, за якими критеріями (параметрами) буде відбуватися кримінологічне спостереження; з'ясування того, як нормативно закріпити та інтегрувати кримінологічний моніторинг у загальну політику з протидії злочинності; збирання даних, отриманих унаслідок кримінологічного моніторингу; здійснення аналізу отриманих даних і доведення певного проміжного висновку до уповноважених осіб (так, наприклад, дані, зібрані волонтерською громадською організацією стосовно стану злочинності в певному районі міста можуть бути передані до органу Національної поліції, який повинен використати зазначену інформацію задля досягнення загальнодержавної цілі щодо викорінення злочинності на теренах держави).

Функціональні засади здійснення кримінологічного моніторингу відображають більшою мірою процедурні та телеологічні його характеристики. Серед останніх, слід, перш за все, звернути увагу на діяльнісну природу моніторингу: він не існує в об'єктивній дійсності як певний автономний феномен значного ступеню абстрагування, відокремлений від суб'єкта кримінологічної практики, а складається з низки послідовних дій, що вчиняються уповноваженими особами (або ж ініціативними дослідниками) за заздалегідь визначеною науково обгрунтованою методикою. Остання передбачає, по-перше, стадійну диференціацію процесу моніторингу, а по-друге, змістовне насичення відповідних стадій конкретними видами діяльності, які в системі складають спостереження, тобто передбачають: а) збирання кримінологічної інформації; б) іiї аналіз; в) узагальнення; г) оцінювання. Кожна із цих підгруп діяльності як складова спостереження в кримінологічному моніторингу володіє власною темпорально, методично й методологічно визначеною специфікою (Коваленко, 2018: 134).

Серед недоліків, які пов'язані із застосуванням кримінологічного моніторингу можна віднести відсутність: єдиного підходу до проведення кримінологічного моніторингу; єдиних критеріїв оцінки ефективності кримінологічного моніторингу; нормативної основи, тобто правового підгрунтя для реалізації кримінологічного моніторингу (не вистачає правових актів, які б більш повно регулювали питання кримінологічного моніторингу, як на всеукраїнському рівні, так і на місцях); методики, за якою можна було б оцінити ефективність превентивної діяльності, яка проводиться.

Інший підхід до проблеми кримінологічного моніторингу запропонував А. П. Закалюк (Закалюк, 2008: 159). На його думку, рецидивну злочинність слід вивчати за допомогою методу екстремального групування параметрів. Він виділив такі істотні ознаки: відношення сумарного реально відбутого строку покарання у виді позбавлення волі до сумарного терміну покарання, призначеного за вироком судів, - більше чи менше 3/4 терміну; вік на момент останнього звільнення - до або понад 30 років; сумарний реальний термін перебування у місцях позбавлення волі - більше або менше трьох років.

На даний час виокремлюють такі складові частини кримінологічного моніторингу: підготовку чіткої теоретичної бази з чітким визначенням усіх істотних моментів щодо моніторингу, його цілей, завдань тощо; з'ясування соціальної обстановки в регіоні, визначення можливих змін; кримінальну обстановку в регіоні, що досліджується (усі статистичні дані, що характеризують рівень злочинності на певній території).

Методичні основи проведення моніторингу розробляються без попереднього дослідження стосовно масштабів поширення злочинності на території України та без урахування моментів, характерних лише для окремо взятих регіонів (часто за основу беруть певні шаблони, вироблені відповідними комітетами правоохоронних органів, наприклад МВС). 3 огляду на такий підхід, для дієвого використання кримінологічного моніторингу необхідно залучати широке коло фахівців з різних галузей на кшталт соціологів, психологів, психіатрів, спеціалістів $з$ кібернетики тощо (Сметаніна, 2016: 74).

Вагомими недоліком є також те, що зазвичай різні відомства обирають спосіб учинення кримінологічного моніторингу на власний розсуд, з огляду на власні відомчі інтереси й завдання, які подекуди формулюються вкрай вузько.

Ю. Орлов та Д. Миронюк висловили думку, що кримінологічний моніторинг (якщо його розглядати в структурно-функціональному розрізі) є певним видом оптимізації елементів самоорганізації суспільства із системою протидії злочинності шляхом отримання від соціуму найбільш повної, сучасної, науково обгрунтованої, упорядкованої, аналітично обробленої й прогностично адаптованої інформації про обопільні параметри функціонування, що розглядаються крізь призму завдань суб'єктів кримінально-превентивної діяльності, у зниженні рівня й характеру кримінальних загроз (Орлов, 2014: 161).

Кримінологічний моніторинг, проведений на загальнодержавному рівні, а також на місцях, може надати інформацію, необхідну для визначення $з$ тим, якого саме інструментарію не вистачає державним органам, щоб побороти злочинність. Для реалізації подібного завдання потрібно виконати таке: надати правоохоронним органам, передусім Національній поліції, реальні повноваження щодо проведення ранньої профілактичної діяльності запобігання злочинності, адже тільки чітко продуманий правовий механізм може стати запорукою усунення подібних недоліків); запровадити систему норм, які б не лише допомогли в регулюванні взаємодії між відомствами, а й чітко визначили процес обміну статистичною інформацією кримінологічних 
досліджень і характеристиками злочинності; налагодити взаємодію між правоохоронними органами, прокуратурою, судами, прикордонними, митними органами й закордонними колегами, які протидіють організованій злочинності (це пояснюється тим, що фактично наш світ нині є мультикультурним та інтернаціональним, а отже, складно боротися зі злочинністю автономно, відхрестившись від закордонних колег); налагодити програми адаптування злочинців, які повернулися до нормального життя після тривалого перебування в місцях позбавлення волі (радянська система наразі зруйнована, а нова ще не вибудована; контролювати криміногенну обстановку в країні й вчасно реагувати на зміни; здійснювати прогнозування розвитку криміногенної ситуації, щоб вчасно можна було зреагувати й застосувати адекватні заходи 3 протидії злочинності, яка може поширюватися; визначитися з першочерговими завданнями та встановити терміни їх реалізації, намагаючись не порушувати визначених термінів (особливо для ранньої профілактики запобігання злочинності); втілити в життя тактичні дії з розподілу задач між державними органами й організаціями, які беруть участь у реалізації загальнодержавного завдання щодо боротьби зі злочинністю, чітко визначити розмір фінансових дотацій, передбачити інші заходи, спрямовані на досягнення поставленої мети; відмітити стратегічні успіхи після виконання основних етапів, перелічених вище, закріпити позитивний досвід і спробувати ще його покращити; чітко визначити терміни підбиття підсумків, визначити порядок складання звітності й порядок контролю цієї звітності.

У діяльності органів Національної поліції, для кримінологічного моніторингу необхідним є таке: виявлення кримінальної ситуації в державі, надання оцінки зазначеній ситуації, визначення із територіями, де найбільш потужно розвинута злочинність (для втілення відмічених дій, представникам поліції потрібно прискіпливо й професійно реагувати на будь-які звернення громадян щодо вчинення злочинів); здійснення аналізу існуючих програм по боротьбі зі злочинністю незалежно від успішності їх реалізації; дослідження роботи всіх систем держави, пов'язаних із боротьбою із злочинністю, для вирахування типових помилок; вивчення можливостей із застосування психологічної допомоги особам, які відбули кримінальне покарання задля їх адаптування до нормального життя (часто покарання, застосоване до особи є неефективним, тому що під впливом перебування в умовах в’язниці в особи відбуваються невиправні процеси видозміни психічного стану, подекуди трапляються випадки суттєвої деградації особистості; з'ясування громадської думки щодо ступеня готовності громадського суспільства брати на себе відповідальність за профілактичні дії серед молоді (зрозуміло, що лише Національна поліція чи інші правоохоронні органи не в змозі самотужки побороти процеси залучення молоді до злочинної діяльності, яка певним чином романтизована художніми фільмами та літературою (нібито злочинці живуть красиво та успішно); проведення перевірок ефективності діяльності правоохоронних органів для своєчасного корегування та виправлення помилок (саме правоохоронні органи реалізують кримінальну політику країни, координують їі, визначають пріоритетні вектори розвитку).

Потребує також встановлення ефективного контролю над регіональним криміногенним простором подолання корупції, злочинності у сфері економіки, у сфері використання виробничих, природних та інтелектуальних ресурсів. Це матиме наслідки не лише у вигляді підвищення добробуту, безпеки і якості життя населення, а за рахунок зменшення тиску злочинності на суспільні відносини, обумовить збільшення дохідної частини регіонів мінімум в 3 рази. 3 метою вдосконалення запобіжної діяльності пропонується впровадити в практичну діяльність обласних OBC таких новітніх технологій, як системи GPS-стеження, GPS-моніторинг, GPS-навігація. Сучасні технічні досягнення за допомогою цих систем дають можливість здійснювати високоточне позиціювання різного роду об'єктів на місцевості; встановлювати точне місцезнаходження транспорту, людей, співробітників; здійснювати моніторинг маршруту пересування та скорості об’єктів; обирати найбільш зручні напрямки руху патрулів поліції та автотранспорту; забезпечувати контроль за їх місцем знаходження та пересуванням.

Загалом сутність удосконалення запобіжної діяльності поліції на перспективу можна охарактеризувати як підвищення рівня інтелектуального впливу на цей процес, залучення сучасних інтернет-технологій для збору, аналізу та зберігання даних, а також кримінологічного прогнозування.

Висновки. Проведене дослідження дозволяє зробити висновки про те, що під поняттям «кримінологічний моніторинг» потрібно розуміти спеціально організовану, систематичну та планомірну діяльність, метою якої є оптимізація системи протидії та запобігання злочинності шляхом отримання від соціуму найбільш повної та обгрунтованої інформації, подальшої іiі обробки і систематизації. Значення кримінологічного моніторингу в діяльності поліції є надзвичайно значущим, оскільки в сучасному інформаційному суспільстві застосування кримінологічного моніторингу як спеціалізованої інформаційної технології має на меті виконання низки функцій, що прямо пропорційно впливають на ефективність виконання поліцією завдань, покладених на неї суспільством і державою, шляхом проведення активної аналітичної роботи. Водночас застосування кримінологічного моніторингу передбачає передусім роботу з інформацією, ії значними обсягами, що за своєю формою та суттю є більш безпечним, аніж безпосередня робота оперативних співробітників з отримання відповідної інформації, яку в подальшому застосовують для розкриття злочинів. Без належної взаємодії поліції з населенням неможливо казати про якісний кримінологічний моніторинг, якісну протидію злочинності.

\section{Список використаних джерел:}

1. Блажівський Є.М. Моніторинг протидії злочинності в Україні: монографія / Є.М. Блажівський. Харків: Золота миля, 2013. $-372 \mathrm{c}$. 
2. Блажівський Є.М. Аналітична робота в системі моніторингу протидії злочинності / Є.М. Блажівський // Науковий вісник Національної академії Служби безпеки України. - 2013. - № 47. - С. 157-165.

3. Закалюк А.П. Курс сучасної української кримінології: теорія і практика: у 3-х кн. / А.П. Закалюк. - Київ: Ін Юре, 2008. - Кн. 3: Практична кримінологія. -320 с.

4. Злочинність і протидія їй в умовах сингулярності: тенденції та інновації // зб. тез доп. наук.-практ. конф., присвяч. пам’яті члена Правління Кримінол. асоц. України, проф. Тетяни Андріївни Денисової (м. Харків, 16 квіт. 2021 р.) Харків : ХНУВС, 2021. - 464 с.

5. Коваленко А.В. Поняття кримінологічної політики держави в діяльності поліції в Україні // А.В. Коваленко / Науковий вісник ДДУВС. - 2016. - № 4 (84). - С. 223-229.

6. Коваленко А.В. Наукові засади здійснення кримінологічного моніторингу: сутність і значення для діяльності Національної поліції України / А.В. Коваленко // Збірник наукових праць Прикарпатський юридичний вісник. 2018. - № 3 (24). - С. 131-135.

7. Коваленко А.В. Кримінологічний моніторинг: сутність ізначення для Національної поліції України / А.В. Коваленко // Актуальні проблеми законодавства України. - Одеса: ГО «Причорноморська фундація права», 2018. - С. 91-94.

8. Коваленко А.В. Кримінологічний вимір поліцейської діяльності в Україні: монографія / А.В. Коваленко. - Херсон: Видавничий дім «Гельветика», 2019. - 356 с.

9. Орлов Ю.В. Кримінологічний моніторинг ефективності правового регулювання як інструмент протидії злочинності / Орлов Ю. В., Миронюк Д. М. // Вісник Кримінологічної асоціації України. - 2014. - № 6. - С. 161-167.

10. Орлов Ю.В. Політико-кримінологічна теорія протидії злочинності: монографія / Ю.В. Орлов. - Харків: Діса-полюс, 2016. $-656 \mathrm{c}$.

11. Сметаніна Н.В. Наукові підходи до теорії злочинності у сучасній українській кримінології / Н.В. Сметаніна //за заг. ред. В. В. Голіни. - Харків: Право, 2016. - 192 с.

12. Сучасні кримінологічні дослідження: методи, напрями, перспективи // Збірник тез міжнарод. наук. - практ. круглого столу. - Київ: ДНДІ МВС України, 2019. - 188 с.

\section{References:}

1. Blazhivsjkyj, Je. M. (2013) Monitoryngh protydiji zlochynnosti v Ukrajini: monoghrafija [Monitoring the fight against crime in Ukraine: monograph] Kharkiv: Zolota mylja [in Ukrainian].

2. Blazhivsjkyj, Je. M. (2013) Analitychna robota v systemi monitorynghu protydiji zlochynnosti [Analytical work in the system of monitoring the fight against crime]. Naukovyj visnyk Nacionaljnoji akademiji Sluzhby bezpeky Ukrajiny Scientific Bulletin of the National Academy of Security Service of Ukraine, 47,157-165.

3. Zakaljuk, A. P. (2008) Kurs suchasnoji ukrajinsjkoji kryminologhiji: teorija i praktyka. [Course of modern Ukrainian criminology: theory and practice] (Vols. 1-3). Kyiv: In Jure. Praktychna kryminologhija [in Ukrainian].

4. Zlochynnist i protydiia yii $\mathrm{v}$ umovakh synhuliarnosti: tendentsii ta innovatsii (2021) [Crime and counteraction to it in the conditions of singularity: tendencies and innovations]. Zb. tez dop. nauk.-prakt. konf., prysviach. pamiati chlena Pravlinnia Kryminol. asots. Ukrainy, prof. Tetiany Andriivny Denysovoi (m. Kharkiv, 16 kvit. 2021 r.) - Collection of abstracts ext. scientific-practical conference dedicated to the memory of a member of the Board of Criminoles. Association of Ukraine, prof. Tatiana Andreevna Denisova (Kharkiv, April 16, 2021) (p. 464) Kharkiv: KhNUVS [in Ukrainian].

5. Kovalenko, A.V. (2016) Ponjattja kryminologhichnoji polityky derzhavy v dijaljnosti policiji v Ukrajini [The concept of criminological policy of the state in the activities of the police in Ukraine]. Naukovyj visnyk DDUVS-Scientific Bulletin of the State Department of Internal Affairs, 4 (84), 223-229.

6. Kovalenko, A.V. (2018) Naukovi zasady zdijsnennja kryminologhichnogho monitorynghu: sutnistj i znachennja dlja dijaljnosti Nacionaljnoji policiji Ukrajiny [Scientific principles of criminological monitoring: essence and significance for the activity of the National Police of Ukraine] Zbirnyk naukovykh pracj Prykarpatsjkyj jurydychnyj visnyk - Collection of scientific works Prykarpattya Legal Bulletin, 3 (24), 131-135 [in Ukrainian].

7. Kovalenko, A.V. (2018) Kryminologhichnyj monitoryngh: sutnistj i znachennja dlja Nacionaljnoji policiji Ukrajiny [Criminological monitoring: essence and significance for the National Police of Ukraine]. Aktualjni problemy zakonodavstva Ukrajiny - Actual problems of the legislation of Ukraine (pp. 91-94) Odesa: GhO «Prychornomorsjka fundacija prava» [in Ukrainian].

8. Kovalenko, A.V. (2019) Kryminologhichnyj vymir policejsjkoji dijaljnosti v Ukrajini: monoghrafija [Criminological dimension of police activity in Ukraine: monograph]. Kherson: Publishing House «Helvetica» [in Ukrainian].

9. Orlov Ju. V. \& Myronjuk D. M. (2014) Kryminologhichnyj monitoryngh efektyvnosti pravovogho reghuljuvannja jak instrument protydiji zlochynnosti [Criminological monitoring of the effectiveness of legal regulation as a tool to combat crime] Visnyk Kryminologhichnoji asociaciji Ukrajiny - Bulletin of the Criminological Association of Ukraine, 6, 161-167 [in Ukrainian].

10. Orlov, Ju.V. (2016) Polityko-kryminologhichna teorija protydiji zlochynnosti: monoghrafija [Political and criminological theory of crime prevention: monograph]. Kharkiv: Disa-poljus [in Ukrainian].

11. Smetanina, N.V. (2016) Naukovi pidkhody do teoriji zlochynnosti u suchasnij ukrajinsjkij kryminologhiji [Scientific approaches to the theory of crime in modern Ukrainian criminology]. V. V. Gholiny (Ed.). Kharkiv: Pravo [in Ukrainian].

12. Suchasni kryminologhichni doslidzhennja: metody, naprjamy, perspektyvy (2019) [Modern criminological research: methods, directions, prospects] Zbirnyk tez mizhnarod. nauk. - prakt. krughlogho stolu-Collection of international theses scientifical and practical round table (p. 188) Kyiv: DNDI MVS Ukrajiny [in Ukrainian]. 